\title{
Protein Lin-37 Homolog
}

National Cancer Institute

\section{Source}

National Cancer Institute. Protein Lin-37 Homolog. NCI Thesaurus. Code C162417.

Protein lin-37 homolog (246 aa, $28 \mathrm{kDa}$ ) is encoded by the human LIN37 gene. This protein plays a role in the regulation of cell cycle-dependent gene expression. 